\title{
Creative methods of innovation process management as the law of competitiveness
}

\author{
Lidiya I. Plotnikova ${ }^{a^{*}}$ and Mykola V. Romanenko ${ }^{a}$
}

${ }^{a}$ Department of Management and Marketing, Faculty of Business Administration and Law, Kyiv University of Market Relations, Kyiv, Ukraine

\section{H R O N I C L E}

Article history:

Received: December 11, 2018

Received in revised format: January 7, 2019

Accepted: January 28, 2019

Available online:

January 28, 2019

Keywords:

Creativity

Creative methods

Innovation process

Competitiveness

Enterprise

Management

\section{A B S T R A C T}

\begin{abstract}
The research paper studies the topical problem of increasing the competitiveness of modern enterprises through the application of creative methods of innovation process management. The expediency of the use of creative methods of the innovation process management is revealed, which is predetermined by the necessity of the formation of long-term competitive advantages in the modern conditions of operation of the enterprises at the level of management tools. To achieve the goals set in the research paper, a system of general scientific and special methods of studying processes and phenomena in their interrelation and development is used, namely: system approach, methods of analysis, synthesis, modeling, systematization, grouping, logical generalization, structural and logical analysis. The research paper presents the role and place of creative management methods in an enterprise management system, which characterize the ways of influencing the management of an enterprise on the activity and interaction of employees of an enterprise involved in the creation of innovative ideas, products and solutions. The place of creative management methods as a tool for achieving the goals of providing innovation-oriented development of enterprises is grounded, which is a stable prerequisite for ensuring the competitiveness of companies in modern highly competitive innovative product markets. Recommendations for implementation of creative methods of innovation activity management of enterprises have been formed; the procedure and the main directions of the solution of existing problems of implementation of the innovation process at enterprises are proposed. The results of this research paper should be considered in the context of their importance to stimulate innovation-oriented development of enterprises, in particular, in the context of the vital need for the formation of sustainable competitive advantages under the conditions of liberalization of markets and globalization.
\end{abstract}

(C) 2019 by the authors; licensee Growing Science, Canada

\section{Introduction}

In today's economy, innovation forms the basis for economic growth strategies, the development of companies and the formation of the foundations of the country's economic development. In the perception of innovation and innovation process, scientists increasingly deviate from the traditional, classical understanding of this phenomenon towards a variety of phenomena, processes and events that form the possibilities of creating new products, models, technologies and services at different levels and in different contexts. In the view of management practice, all enterprises, even small businesses, are currently strongly influenced by competition at the level of innovation, often at different levels and in different fields of activities at the same time (e.g. new products, technologies, organization, relations 
with partners, etc.). The performance of enterprises in this area largely depends on their competence, managerial skills and implemented innovative strategies (Khan et al., 2017). It should be noted that in today's business environment, the company's competitiveness is ensured by the creation of a product that is innovative and has features that differentiate it from the product of competitors and provide the company an advantage in the market. An important aspect of achieving such advantages is to create conditions in the company where innovation activity is not a series of inconsistent actions by individual, creative and initiative employees, which ultimately leads (and which often does not lead) to the creation of an innovation, but a systematic managed process, which is implemented continuously and results in the consistent improvement of production, organizational and managerial processes at the enterprise.

In today's economy, this position, which determines the importance of a systematic approach to the implementation of the innovation process, is not a secret. More and more companies are focusing on the need for efficient management of the innovation process, while forming certain theoretical models that describe the most rational ways to manage innovation, creating structured automation and decisionmaking support systems that are innovative products available in the market (Yusr et al., 2018).

Thus, the situation arises when the competition moves from the level of the most innovative product to the level of organization and management of the process of its creation and market launch. More and more standard, reasonable and rational schemes, models, and management techniques are emerging to increasingly formalize the management process, making it much more effective compared with the management of past decades.

This situation leads to the fact that in the process of management of innovations, managers more and more often have a well-grounded, practically tried and tested, formalized and, to the extent possible, automated management tool (approach, method, methodology, standard, etc.). Such a trend is quite positive for the development of the innovation market, and while absolute achievement of the limit of saturation with effective technologies of the process of innovation management is not yet observed, the vector of development of the theory, methodology and practice of management, while simultaneously radically accelerating the process of knowledge sharing, testifies to the possibility of such "over-saturation" of the management tool market with effective formal procedures and solutions.

In this sense, it is important to note that for routine management activities this situation is relatively favorable, while the availability of such tools for most managers (free of charge or for a fee), especially in the area of creating innovations, leads to leveling of the competition aspect in management and business organization - access to an effective management process for many will lead to the possibility, in turn, of creating a competitive product by many (as a result of effective investment process) and reduce the potential for creating competitive advantages of individual market participants.

This problem is solved by expanding the role of nonstandard, creative solutions in the field of innovation process management, which is the subject of this research paper. It is such solutions, ideas, methods, approaches that allow a particular company to get a specific advantage in managing the innovation process and create an innovative product that is more in demand in the market (make it faster, cheaper, etc.). The primary objective of this paper is to describe the enterprise innovation management system using creative methods, focused on improving the competitiveness of enterprises, as well as identifying the prerequisites and forming a sequence of effective application of creative enterprise management technologies in modern conditions.

\section{Literature review}

The problem of increasing the efficiency of the innovation process due to the intensification of creative activity in modern enterprises is considered in the world scientific literature quite substantively and widely. In this regard, it is especially important to distinguish works that rely on an empirical basis and have significant theoretical and practical value. Thus, this paper presents a developed research model 
for managing innovations (Azis et al., 2017) and the main success factors in the creative field are identified by analyzing the conditions of activity of successful enterprises in Indonesia.

Potudanskaya et al. (2017) considered the problems of the formation and development of the innovative potential of industrial workers using the example of light industry. The research paper determined the types of innovations suitable for development in this area. The authors proposed a mechanism for managing the innovation potential of enterprise staff taking into account industry specifics.

Nasiri et al. (2016) analyzed some German corporations and enterprises and showed that stronger enterprises pay more attention to innovations and, thus, receive greater profits. In such companies, various rules and regulations are developed and widely used to stimulate the creative activity of employees.

Dornberger and Suvelza (2012) found that the majority of managers work on innovation in the late stages of the innovation process, which are characterized by structured processes, clear procedures and documented duties and roles of employees, despite the fact that much more efficient levers for generation of new ideas and improving the competitiveness of enterprises on the basis of innovation exist in the early stages, called the stages of "fuzzy innovation interface (FFEI)". Instead of relying on the sufficiency of time for making innovative decisions, the company should decide on which opportunities and ideas to choose and implement quickly already at the initial stage, even if it is connected with uncertainty and risk. The correct set of methods and processes for collecting and analyzing information can help identify risk factors, reduce uncertainty, and at the same time, the authors consider the entrepreneurial spirit of taking a certain risk a necessary condition for the success of an enterprise in the competitive struggle.

Hotho and Champion (2010) believe that in modern conditions the pressure on the innovation process is increasing, since technological cycles are changing faster. Organizations need to effectively balance management practices, which is difficult to achieve, as this threatens organizational tension, which can ultimately jeopardize the company's innovative potential.

Krayneva et al. (2017) focused on the study of the determinants and structure of the economic innovation potential, as well as the existing methods for its assessment. The results of this study allow identifying the key issues and major problems of research and development, as well as formulating a comprehensive plan for strategic management and direction of innovative development in the context of the economic problems of a particular country.

Particular attention should be paid to the works on the role of human capital, its creativity in creating the conditions for successful innovation activities of enterprises and their achievement of competitiveness. This issue is presented, in particular, in several studies (e.g. Kucharčíková et al., 2018; Lee et al., 2018). It is also important to rely on the research process of the works which deal with the analysis and formation of the models associated with an effective innovation process in the developed countries, (Lema et al., 2018; Seidel-Sterzik et al., 2018). Significance of innovation in forming the competitiveness of companies is quite interestingly reflected in the works of Bugador (2016) and Yu et al. (2017).

It should be noted that, according to modern researchers (e.g. Borrás, 2016; Borrás \& Edquist, 2013; 2015; Slivko \& Theilen, 2014), intangible assets (information, knowledge, skills and skills of workers, the relationship between them), rather than traditional, material factors of production, are increasingly becoming a source of competitiveness of enterprises in modern conditions. In such a situation it is necessary to ensure the strategic compliance of the enterprise's activities with the level of development of the technical and technological basis of modern production (Sadeghi \& Rad, 2018).

This paper focuses on enriching the scientific understanding of modern economic processes by comprehension, theoretical generalization and structuring the problems of managing innovation processes 
in enterprises to ensure competitiveness as the dominant of enterprise development in market conditions, distinguishing the place of creative technologies of managing the economy as a tool of ensuring the competitiveness at the level of management decisions.

The solution of these tasks, as expected, will help to distinguish the place of creative management technologies as the most important priority of the innovation-oriented development of a modern enterprise and ensuring its competitiveness.

\section{Research methodology}

To achieve the objectives of this paper, a system of general scientific and special research methods is used; namely a system-structural approach, methods of analysis and synthesis to represent concepts and phenomena. The processes and phenomena that characterize the innovative activity of an enterprise are considered in the research paper in their relationship and development. Thanks to the use of a system-structural approach, the innovative development of an enterprise is presented as a set of elements and properties with their interaction forming a new, more effective integrity.

The methods of theoretical modeling (when substantiating the procedure of formation and application of creative technologies in relation to the innovation process at the enterprise), systematization, grouping, (when identifying problems, factors and conditions conducive to the development of innovation in modern enterprises as the basis of their competitiveness), logical generalization, structural and logical analysis (in the process of forming areas of action at the micro level that contribute to enterprise competitiveness) were also used in the research paper.

The theoretical basis of the research paper was the key provisions of modern economic theory and modern concepts of innovative development at the micro level, presented in the scientific works of leading scientists.

\section{Results}

Innovation is the key to competitiveness, and the pace of change in innovative process management technologies shows that only an enterprise that can creatively introduce innovative changes, and not just formalized and standard ones, can survive in the market. The innovation process involves the process of creating, introducing and spreading innovation, and the economic essence of innovation and innovation activity are changes that are considered as a source of income. Innovation activity in this context acts as a specific activity of the enterprise (its employees), a set of works which are different in purpose and nature, corresponding to the main stages of the development of innovative processes and aimed at creating and making appropriate and rational changes to the enterprise (Bohashko, 2013; Slivko \& Theilen, 2014). At the same time, it is important to distinguish those areas of improvement, which involve a radical departure from existing so-called "disruptive innovations" as a priority for the development of innovation activities. In the works accomplished by George et al. (2005) and Wright (2003) the authors compared disruptive innovations with supporting ones (built on already existing technology, products/services, market strategy and are based on already existing key competencies) from the point of view of their riskiness and potential benefits to their practical implementation and spread. According to George et al. (2005) 'disruptive innovations stop or reduce the growth of profitability and the potential of creating the value of existing proposals', while these innovations are capable of providing an "explosive growth" of an enterprise. Successful implementation of disruptive innovations essentially depends on the active actions of the management of enterprises in the development of new technologies, the acquisition of new key competencies, the implementation of new knowledge and skills of personnel, the development of product distribution channels or the construction of a new sys-

tem for promoting and implementing innovative goods. Even with the successful implementation of these actions there are risks of lack of interest in the new product from the part of the consumer market, 
the unpredictability of sales and profits, the emergence of new unplanned expenses in the process of implementing innovations and market launch of the innovative product. Creative activity is largely associated with the implementation of innovative ideas of a breakthrough nature (disruptive innovations), while the systemic process of creative work of enterprise employees can realize the potential of quite important and profitable supporting innovations, for example, the result of such supportive innovations was the creation of automatic gearboxes, CDs and DVDs, flash drives, owner face recognition in modern smartphones, which were a continuation of the existing technology. According to George et al. (2005), although all innovative products can have significant growth potential, disruptive innovations have on average a higher growth potential, and this is often caused by competitors ignoring threats to their stable development posed by initiators of disruptive innovations, which can take the form of new technology, a new proposal, a new process or even a new model of enterprise management.

An example of such a disruptive innovation, underestimated at the initial stage of implementation, is the transfer in 1956 by IBM of the largest commercial computer IBM 709 from lamps to germanium transistors. The transistor costed 17 dollars, the lamp - three dollars, but the processing speed of the new computer was six times higher than that of the lamp computer. This is how a new product (transistors) "undermined" another product (lamps) on the basis of lower costs per unit of performance, but not lower unit costs. At the same time, before the use of transistors in the production of computers they were not considered as a threat to the existence of lamps in general. The next step was the invention of an integrated microcircuit in 1959. Replacing discrete transistors reduced the physical dimensions of a computer by $75 \%$ and weight by $67 \%$, and the performance doubled (George et al., 2005).

Wright (2003) indicated that significant positive changes in the efficiency of the company's activity are possible if its management and leading employees understand and can assess what growth in revenue, profits and business value is possible if the company implements an innovation process that enhances differentiation, reduces time to enter the market and allows making competitors' products obsolete. In this context, innovations are considered as a key factor in improving the competitiveness of a company, and creativity is a determining characteristics of the process of creating, implementing and disseminating innovations. It is reasonable to consider creative activities of enterprises (their structural units, employees, management) as an activity that aims at increasing the added market value of an enterprise and strengthening its market position by introducing a creative approach to the problem that presently uses non-standard methods, approaches, solutions and ideas. According to a survey by Deloitte conducted in 2015 in the form of an interview of managers of 100 enterprises (Fig. 1), creativity ranks third among the skills demanded by enterprises and organizations of the public sector in the UK.

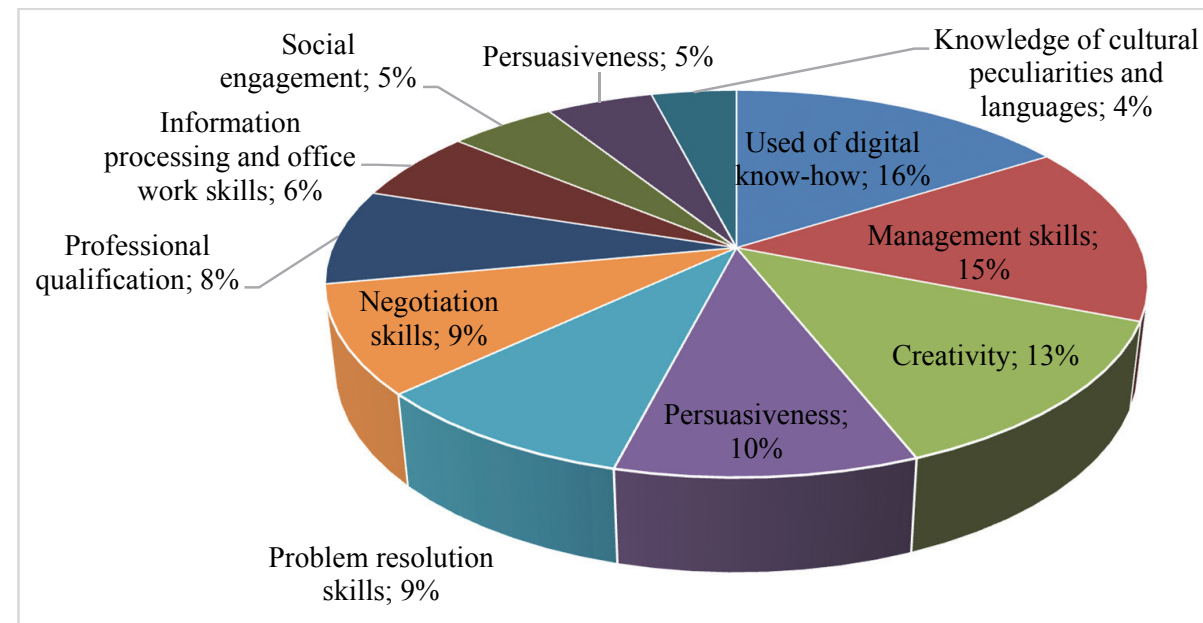

Fig. 1. Skills demanded by UK enterprises and public sector organizations. Source: based on Deloitte 


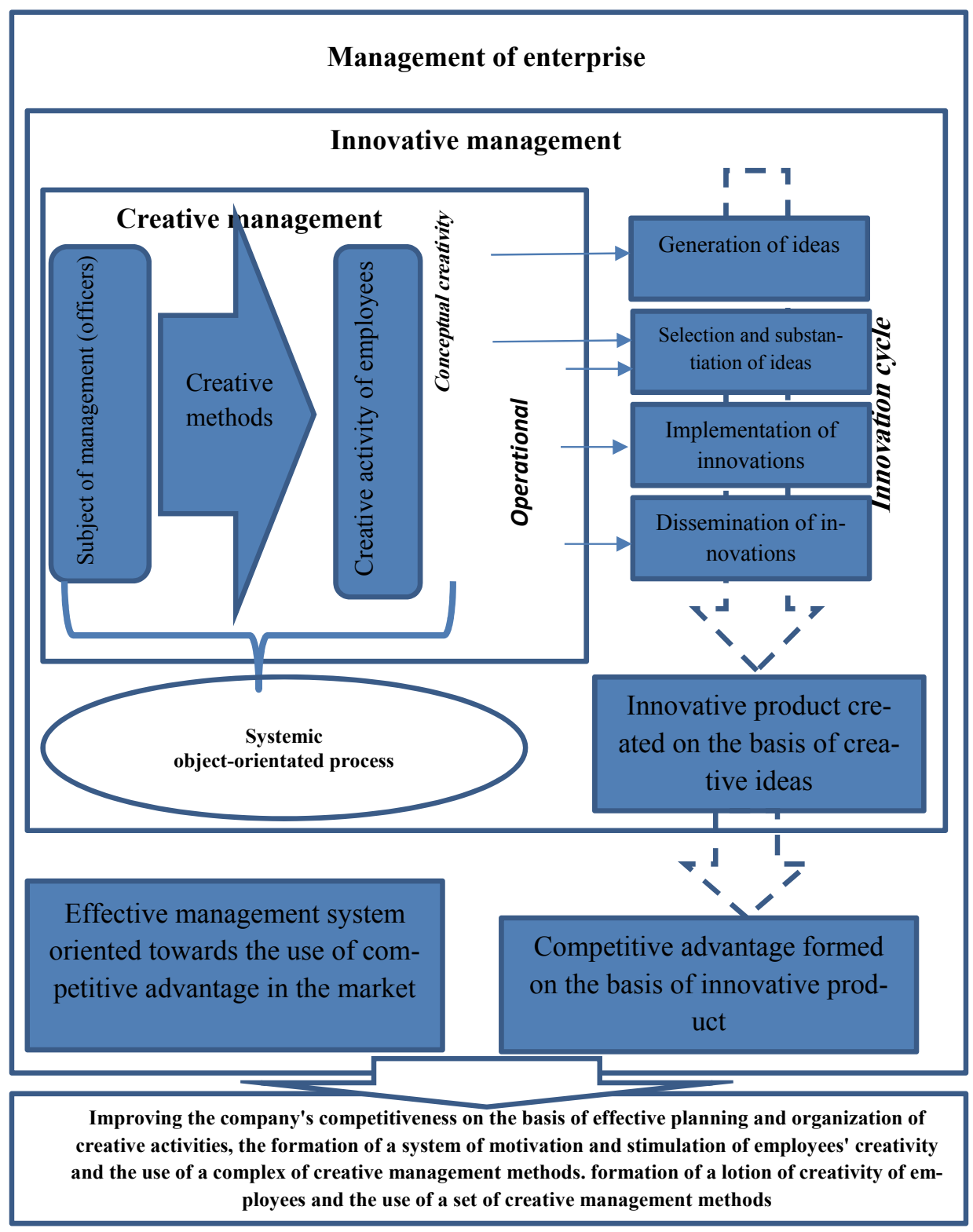

Fig. 2. Innovation activity management system using creative methods, focused on improving the competitiveness of enterprises. Source: author's development.

To a certain extent, one can interpret the results of such studies to urge the role of creativity in the activities of a modern enterprise in the developed countries. At the same time, managers who expect creativity from their subordinates, face a positive response to a large extent, as evidenced by the data from the research of expectations of young employees presented in Deloitte (2014). Thus, according to the study, $70 \%$ of young employees want to be creative in their work. In addition, more than two thirds believe that the task of management is to provide them with opportunities to accelerate the development of their knowledge and creative skills (Deloitte, 2014). The relationship between the innovation process and creativity in management can be represented as a system in which creative management is an integral part of effective innovation management. Creative management technologies in this case act as a tool of managerial influence on the process of creating, introducing and disseminating innovations. The authors propose to present this system in the form of Fig. 2. This scheme represents creativity as an integral element of the innovation process, in which the employees of the company, building and implementing creative ideas, are in turn objects the management for the company's officers. The task of the company's officers is to create an effective system of creative activity management, where its main toolkit should contain creative management methods. They can be differentiated into: 
- administrative (regulations, directives);

- economic (material incentives, bonuses, etc.);

- moral and psychological (encouragement, joint exchange of creative ideas, organization of discussions and competitions, etc.).

These methods can be complementary and contain elements of both material and non-material incentives for employees to creative activity. In this context, creativity in combining standard and non-standard techniques and methods is the basis for the successful formation and implementation in practice of the tools for managing the creative process in each particular enterprise. At the same time, the task of the company's officers is to create favorable conditions for the formation and implementation of creative ideas in the enterprise. The process of creating such conditions can also be considered as a group of creative management methods, in particular, effective creative activity in an enterprise involves the following actions to be carried out by the officers:

- introduction of the elements of creativity in the corporate culture;

- holding competitions on the formation of creative ideas in the enterprise;

- creation of a platform for the exchange of ideas of creative employees and innovators.

Thus, it can be argued that creativity and innovation are complementary to the creative process in an enterprise, the realization of which is to increase the company's competitiveness by creating unique competitive advantages. This advantage can be contained both in the final market product and in the creation of a more efficient system of organization and management of the enterprise, the production system, the wage and motivation system, etc. than those of the competitors. Creativity combines innovative and creative processes: the creation of ideas and the provision of specific solutions is designed to introduce innovations (technical or organizational) into organizations, which are accompanied by changes in the field of management. In our opinion, creativity is a dynamic force that allows achieving increased competitiveness of an enterprise through the involvement of various systems and subsystems of an organization. The result of this relationship is distinguishing two types of creativity in Fig. 2: conceptual creativity (necessary for the development of new products, methods, concepts, etc.) and operational creativity (necessary for the selection and implementation of creative products in practice). While conceptual creativity is the unlimited activity of the imagination, then operational creativity takes into account the criteria of the usefulness of ideas and their transformation into innovations. The result of conceptual creativity is new value, and operational creativity results in a ready-made innovation as a product of creative activity and their implementation. As a result, the creative process leads to the creation of an innovative product, which is the basis for the formation of a new competitive advantage and improving the company's competitiveness in the market. The level of involvement of both types of creativity determines the degree of novelty of emerging innovations. A high level of conceptual creativity at the stage of the formation of ideas and a high level of operational creativity at the stage of their implementation guarantees a breakthrough (radical) innovation, and this requires the formation of an effective targeted system for managing the creative process, while involving a set of creative methods. It is advisable to achieve increasing the competitiveness of modern conditions of enterprises through increased use of creative technologies, primarily in the field of management, which allows creating an effective system for creating and implementing creative solutions and focus the activities of the entire enterprise on the formation and realization of its competitiveness potential. At the same time, it is important to take into account the introduction of creative technologies in the management of enterprises in a systematic and complex process, which may be accompanied by the following problems, in particular:

- requirements for people which are inadequate to the goals of enterprise development, especially if in reality completely different behavior is stimulated;

- the officers' failure to explain the meaning of the planned changes, the topicality of the organization's procreative orientation;

- lack of employee involvement in the decision-making process;

- concealing possible problems with the implementation of creative ideas in practice, the idealization 
of the creative process;

- manipulating the fear of employees (fear of dismissal, fear of incompetence, etc.) as a means of stimulating creativity and work towards the creation of innovations;

- making decisions that do not take into account the complex nature of existing problems (limited perspective);

- concentration on ready-made solutions without understanding the essence of the problem of the formation of the enterprise's competitiveness in a dynamic market environment.

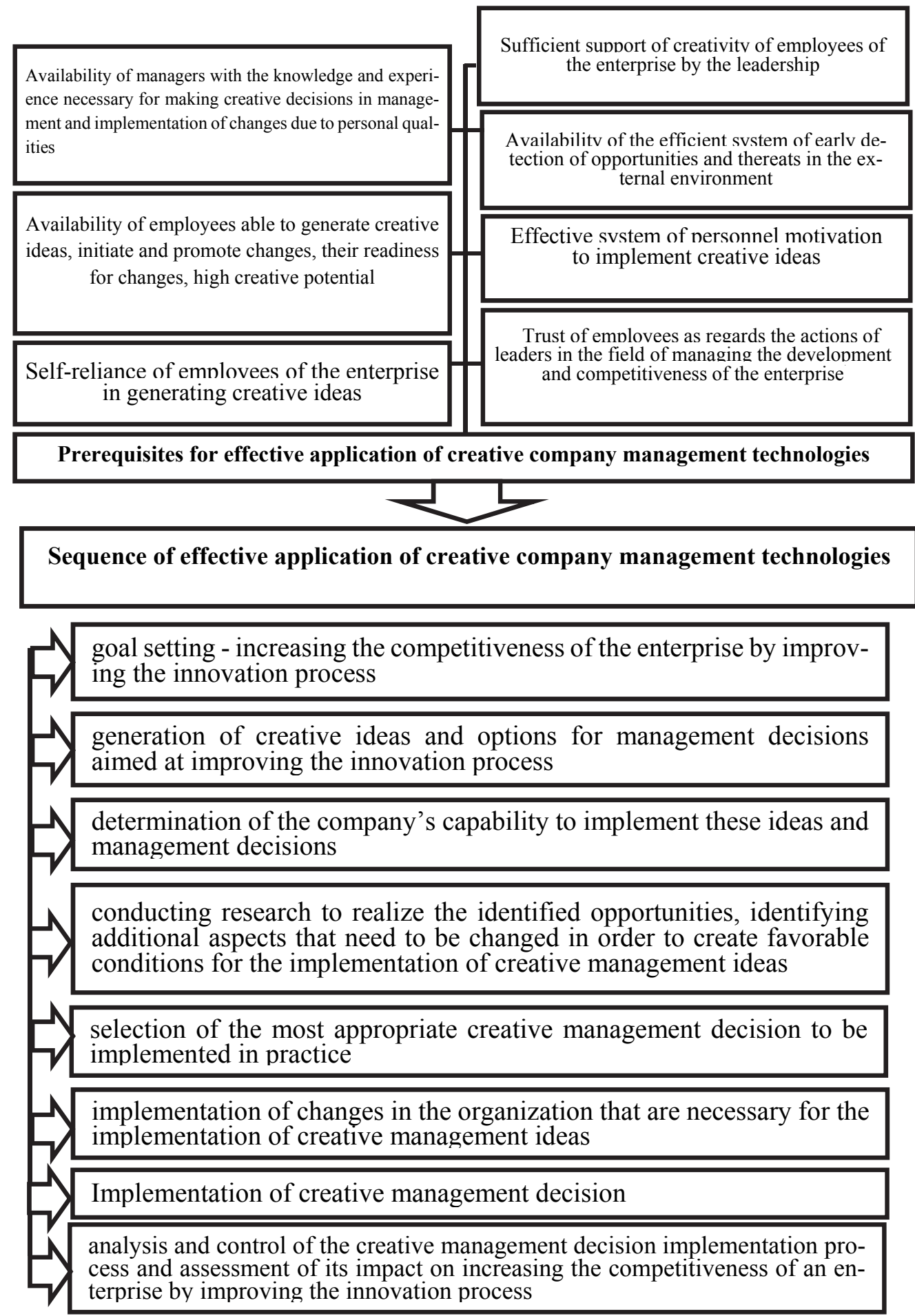

Fig. 3. Prerequisites and sequence of effective application of creative technologies of enterprise management in modern conditions. Source: developed by the author using (Bushuev et al., 2010; Pavlov, 2015; Sokolov \& Yurkan, 2008). 
The authors of the research paper suggests implementing the process of applying creative methods of innovation management in an enterprise by the following sequence and taking into account (Fig. 3). The logical problem of activity based on the implementation of creative ideas is the risks associated with the novelty of the tasks. The impact of these risks on the process of achieving the objectives of the project can be reduced by realizing the creative potential of the management team. The most important element that stimulates the creativity of employees is the formation of a corporate culture in which promotion of the creativity of employees plays an important role. Organizations increasingly arrange the so-called creative spaces. Google, the global Internet giant, which has headquarters around the world where informal atmosphere dominates, can be named as an innovator in such activities. The company is aware that only companies that are ready for creative formation and implementation of ideas, especially in the field of management (Segarra \& Teruel, 2014), have chances for successful activity in a highly competitive market environment, which predetermines the possibility of implementing innovative breakthroughs based on creative solutions, carrying out continuous organizational changes based on systematic creative activities of leadership and employees of the enterprise.

\section{Discussions}

In general, the traditional economy deals primarily with material resources, where volume in nature and availability for consumption are limited. In the innovation economy, the concept of rarity of traditional resources is becoming less and less important (Brisbane City Council, 2013; Belk, 2014). The rarity of specific human resources is urged: free time, attention, memory, emotions, taste and creativity. It should be noted that almost every innovation process must begin with creative actions; not every act of creativity will create innovations. Innovations will not be created without creative workers, but it is necessary to create adequate conditions in the company to use their potential. Creativity is a special resource of employees of the organization, a special method of production, and innovation is its effect, which is the final product. Kotter (2012) showed that creativity becomes more intense when people from different fields of knowledge and various disciplines of science and practice collaborate. It is important that such diversity stimulates creativity. Team members should represent different ways and levels of thinking, different views, interest in nuances, or be characterized by a wide range of views. In this process, real thinking must "compete" with imagination. Creativity-oriented cooperation should be dynamic and continuous in order to ensure a free flow of thoughts and new ideas.

Creative management should focus on the transformation of the current reality in order to achieve the strategic goals of the enterprise (Hamacher, 2014). Proceeding from this, the enterprise management system should determine the potential opportunities that are formed for the implementation of both general and other strategies, and not follow these opportunities, so it should be creative in its essence and promote the development of the target market; marketing, commodity, price distribution channels; demand; social, environmental, structural transformations; financial opportunities, etc. The possibility of expanding the capacity of enterprises through organizational improvements should be taken into account. The findings presented in the research paper indicate the existence of an inseparable link between creativity and innovation. Creativity reflects the nature of the processes in a modern enterprise (including the management process), and innovation reflects its effect. Without creating and realizing the creative potential, it is impossible to create and implement new ideas, test them and make the final choice for the implementation in the form of innovation. We can say that creativity is a prerequisite for innovation, but also insufficient, because in each case, creative thinking and action do not necessarily lead to the creation of innovative products that are successful in the market. Creativity is often understood and realized only as a potentially creative activity that does not bring innovative results. Therefore, the principles of goal setting and orientation in the creative process of an enterprise are important. In particular, it is important to determine a clear focus of creativity on the creation of innovations and the achievement of the ultimate goal of improving the company's competitiveness.

The link between creativity and innovation, according to the authors of the research paper, is ensured by the real interest of the leadership of a particular company and its employees in implementation of 
creative ideas and transforming the latter into market innovations. The results of the study carried out in this research paper should be used in the future in the context of studying the theory and methodology of innovative development of enterprises, as well as the use of a creative approach to creating an innovative product.

\section{Conclusions}

This paper has presented characteristics of an enterprise's innovation management system using creative methods focused on improving the competitiveness of enterprises. Prerequisites for the implementation of an innovative model of enterprise development have been identified and a sequence of effective application of creative enterprise management technologies in modern conditions has been formed. The results of the study allow presenting the creative process as an element of the innovation management system and urge the need for a systemic and targeted impact of the company's management on the creative process and the activities of creative employees as an object of management. This kind of functioning that is carried out through a well-grounded set of creative management technologies that can create and develop the competitive advantages of a company and result in increasing its competitiveness.

Further development of the scientific and practical direction helps for the determination of conceptual approaches for the implementation of creative activities in the field of enterprise management. It is also important to use the opportunities provided by factor analysis based on a study of the experience of innovative activities of companies; identification of problems and benefits of the development of creative activity of enterprises; the formation of approaches to the use of creative methods in the management process; evaluation of the use of creative methods in managing innovation in the enterprise.

\section{Acknowledgement}

The authors would like to thank the anonymous referees for constructive comments on earlier version of this paper.

\section{References}

Azis, Y., Darun, M. R., Kartini, D., Bernik, M., \& Harsanto, B. (2017). A model of managing innovation of SMEs in Indonesian creative industries. International Journal of Business and Society, 18(S2), 391-408.

Belk, R. (2014). You Are What You Can Access: Sharing and Collaborative Consumption Online. Journal of Business Research, 67(8),1595-1600.

Bohashko, O.L. (2013). Evolution of Theoretical Approaches to Innovation Development in the Economic Science. Bulletin of the Berdiansk University of Business and Management, 2(22), 23-29.

Borrás, S. (2016). Organisations in Innovation Systems: Entrepreneurship, Intrapreneurship and Public Policy. DBP Working Papers. Copenhagen: Copenhagen Business School.

Borrás, S. \& Edquist, C. (2013). The Choice of Inovation Policy Instruments. Technological Forecastingand Social Change, 80(8), 1513-1522.

Borrás, S. \& Edquist, C. (2015). Education, Training and Skills in Innovation Policy. Science and Public Policy, 42(2), 215-227.

Brisbane City Council. (2013). Digital Brisbane: A strategy for a digitally driven economy, http://www.brisbanemarketing.com.au/Business/Digital-Brisbane/pages/Digital-Strategies.aspx

Bugador, R.C. (2016). The competitiveness of business groups and their affiliates in international operations. Foundations of Management, 8(1), 251-262.

Bushuev, S.D., Bushueva, N.S., Babayev, I.A., Yakovenko, V.B., Grisha, E.V., Dzyuba, S.V. \& Voitenko, A.S. (2010). Creative Technologies in Project and Programme Management. Kyiv: Sammit Knyha. 
Deloitte. (2014). Big demands and high expectations. The Deloitte Millennial Survey. https://www2.deloitte.com/content/dam/Deloitte/global/Documents/About-Deloitte/gx-dttl-2014millennial-survey-report.pdf

Deloitte. (2015). From brawn to brains. The impact of technology on jobs in the UK. https://www2.deloitte.com/content/dam/Deloitte/uk/Documents/Growth/deloitte-uk-insights-frombrawns-to-brain.pdf

Dornberger, U. \& Suvelza G., J.A. (2012). Managing the fuzzy front-end of innovation. Leipzig: Intelligence 4 innovation.

George, M., Works, J. \& Watson-Hemphill, K. (2005). Fast Innovation. New York: McGraw-Hill Education.

Hamacher, S. (2014). Exploring the Frugal Innovation Process - An Empirical Study of a New Emerging Market Phenomenon. Master Thesis. Copenhagen Business School, Center for Business and Development Studies.

Hotho, S. \& Champion, K. (2010). "We are always after that balance" - Managing innovation in the new digital media industries. Journal of Technology Management and Innovation, 5(3), 36-50.

Khan, F., Xuehe, Z., Atlas, F., Khan, K., Pitafi, A., \& Saleem, M. (2017). Impact of absorptive capacity and dominant logic on innovation performance of public sector organizations in Hefei (Anhui Province), China. Management Science Letters, 7(6), 275-284.

Kotter, J. (2012). How the most innovative companies capitalize on today's rapid-fire strategic challenges - and still make their numbers. Harvard Business Review, 90(11), 43-58.

Krayneva, R., Bugaev, A., Zhuravleva, T. \& Vojtovič, S. (2017). Management and promotion of economic innovation potential. Journal of International Studies, 10(1), 146-158.

Kucharčíková, A., Mičiak, M., \& Hitka, M. (2018). Evaluating the effectiveness of investment in human capital in e-business enterprise in the context of sustainability. Sustainability, 10, 3211.

Lee, S.H., Leem, C.S., \& Bae, D.J. (2018). The impact of technology capability, human resources, internationalization, market resources, and customer satisfaction on annual sales growth rates of Korean software firms. Information Technology and Management, 19(3), 171-184.

Lema, R., Rabellotti, R., \& Gehl Sampath, P. (2018). Innovation trajectories in developing countries: Co-evolution of global value chains and innovation systems. European Journal of Development Research, 30(3), 345-363.

Nasiri, A., Alleyne, A.R. \& Yihui, L. (2016). Analysis of innovation management in German enterprises. Cogent Business and Management, 3, 1216727.

Pavlov, V.V. (2015), Potential of creative technologies of light industry enterprises: Characteristics and problems of realization. International Scientific Journal, 6, 136-140.

Potudanskaya, V. F., Borovskikh, N.V. \& Kipervar, E.A. (2017). Problems of formation and development of the innovative potential of workers of light industry enterprises. Espacios, 38(49), 9.

Sadeghi, A., \& Rad, F. (2018). The role of knowledge-oriented leadership in knowledge management and innovation. Management Science Letters, 8(3), 151-160.

Segarra, A., \& Teruel, M. (2014). High-growth firms and innovation: an empirical analysis for Spanish firms. Small Business Economics, 43(4), 805-821.

Seidel-Sterzik, H., McLaren, S. \& Garnevska, E. (2018). A capability maturity model for life cycle management at the industry sector level. Sustainability, 10, 2496.

Slivko, O. \& Theilen, B. (2014). Innovation or imitation? The effect of spillovers and competitive pressure on firms' R\&D strategy choice. Journal of Economics, 112(3), 253-282.

Sokolov, D.V. \& Yurkan, E.I. (2008). Management Innovations. Saint Petersburg: SPbGUEF Publishing House.

Wright, R. (2003). Business-to-Business Marketing: A Step-by-Step Guide. Harlow: Financal Times Management.

Yu, C., Zhang, Z., Lin, C., \& Wu, Y.J. (2017). Knowledge creation process and sustainable competitive advantage: The role of technological innovation capabilities. Sustainability 9, 2280.

Yusr, M., Mokhtar, S., Abaid, W., Perumal, S., \& Fauzi, F. (2018). The antecedents' strategies and processes of product innovation performance. Management Science Letters, 8(11), 1183-1198. 
(C) 2019 by the authors; licensee Growing Science, Canada. This is an open access article distributed under the terms and conditions of the Creative Commons Attribution (CC-BY) license (http://creativecommons.org/licenses/by/4.0/). 